\title{
MENINGKATKAN KEMAMPUAN BERPIKIR KRITIS MATEMATIS SISWA SMP DENGAN MENGGUNAKAN MODEL PENEMUAN TERBIMBING
}

\author{
Wahyu Setiawan \\ kakwahyu3@gmail.com \\ Program Studi Pendidikan Matematika, STKIP Siliwangi
}

\begin{abstract}
ABSTRAK
Kemampuan berpikir kritis matematis di Indonesia pada saat ini masih rendah yang berakibat pada rendahnya kualitas pendidikan di Indonesia, memilih model pembelajaran yang tepat dapat mengoptimalkan kemampuan berpikir kritis matematis siswa. Penelitian ini bertujuan untuk mengetahui peningkatan kemampuan berpikir kritis siswa melalui pembelajaran dengan model penemuan terbimbing, serta membandingkannya dengan siswa yang memperoleh pembelajaran konvensional. Metode yang digunakan dalam penelitian ini adalah metode eksperimen dengan desain pretes postes kelompok kontrol. Populasi pada penelitian ini adalah seluruh siswa SMP Muhammadiyah 6 Bandung kelas VII semester 2 tahun ajaran 2012/2013 dengan pemanipulasian perlakuan dimana kelas VII-D sebagai kelas eksperimen dan kelas VII-B sebagai kelas kontrol. Instrumen yang digunakan adalah soal uraian yang terdiri dari 6 butir soal kemampuan berpikir kritis siswa. Hasil penelitian menunjukkan bahwa peningkatan kemampuan berpikir kritis siswa melalui pembelajaran dengan model penemuan terbimbing lebih baik daripada peningkatan kemampuan berpikir kritis siswa melalui pembelajaran konvensional.
\end{abstract}

Kata Kunci: model penemuan terbimbing, kemampuan berpikir kritis

\begin{abstract}
The ability of critical thinking mathematically in Indonesia at this time is low resulting in low quality of education in Indonesia, choose appropriate learning models can optimize the mathematical ability of students to think critically. This study aims to determine the increase in critical thinking skills of students through guided discovery learning model, and compared with students who received conventional learning. The method used in this study is the experimental method with pretest posttest control group design. The population in this study were all students of SMP Muhammadiyah 6 Bandung VII class 2nd semester academic year 2012/2013 with the manipulation of treatment where the class VII-D as the experimental class and the class VII-B as the control class. The instrument used is a matter of description consisting of 6 items critical thinking skills of students. The results showed that increasing students' critical thinking skills through guided discovery learning model is better than the increase in critical thinking skills of students through conventional learning.
\end{abstract}

Keywords: model of guided discovery, critical thinking skills

\section{A. PENDAHULUAN}

Kualitas pendidikan Indonesia dinilai masih tergolong rendah, hal ini dapat terlihat dari hasil tes Trend in International Mathematics and Science Study (TIMSS), lembaga yang mengukur dan membandingakan kemampuan matematis siswa-siswi antar Negara, penguasaan matematika siswa tingkat 8. Tahun 1999 Indonesia menduduki peringkat ke-32 dari 38 negara yang diteliti. Tahun 2003 Indonesia menduduki peringkat ke-36 dari 45 negara yang diteliti, pada tahun 2007 Indonesia 
menduduki peringkat ke-41 dari 48 negara yang diteliti, rerata skor yang diperoleh siswa-siswi Indonesia adalah 397. Skor ini masih jauh dari skor internasional yaitu 500 (Herlanti, 2009).

Untuk meningkatkan kualitas pendidikan tersebut, sekolah dituntut untuk menyiapkan peserta didik agar memiliki berbagai macam kemampuan, sehingga mereka dapat menjadi manusia yang berkualitas dan mampu bersaing. Kemampuan yang harus dimiliki tersebut antara lain adalah kemampuan berpikir kritis. Berpikir kritis merupakan bagian penting dari tujuan pembelajaran matematika. Hal ini dapat dilihat dari tujuan pembelajaran matematika di sekolah menurut Depdiknas (dalam Herawati, 2006: 1) yang menekankan siswa supaya memiliki: (1) kemampuan yang berkaitan dengan matematika yang dapat digunakan dalam memecahkan masalah matematika, pelajaran lain ataupun masalah yang berkaitan dengan kehidupan nyata; (2) kemampuan menggunakan matematika sebagai alat komunikasi; (3) kemampuan menggunakan matematika sebagai cara bernalar yang dapat dialihgunakan pada setiap keadaan seperti berpikir logis, berpikir kritis, berpikir sistematis, jujur, disiplin, dalam memandang dan menyelesaikan masalah.

Peningkatan prestasi belajar matematika siswa diharapkan mampu tercapai dengan meningkatkan kemampuan berpikir kritis matematis siswa. Menurut Ennis (dalam Hassoubah, 2004) berpikir kritis ialah kemampuan memberi alasan (reasonable) dan reflektif yang difokuskan pada apa yang diyakini dan dikerjakan. Reflektif berarti mempertimbangkan secara aktif, tekun dan hatihati terhadap segala alternatif sebelum mengambil keputusan. Dalam pendidikan, berpikir kritis telah terbukti mempersiapkan peserta didik berpikir pada berbagai disiplin ilmu, menuju pemenuhan sendiri akan kebutuhan intelektual dan mengembangkan peserta didik sebagai individu berpotensi

Pembelajaran matematika dengan model penemuan terbimbing yang bertujuan untuk meningkatkan kemampuan berpikir kritis matematis siswa menjadi salah satu solusi. Siswa dituntut untuk menemukan sesuatu yang baru dalam diri siswa dengan bimbingan dari guru agar siswa tidak merasa kesulitan dalam pembelajaran. Pembelajaran dengan penemuan terbimbing, siswa didorong untuk belajar sebagian besar melalui keterlibatan aktif mereka sendiri dengan konsepkonsep dan prinsip-prinsip. Selain itu, dalam pembelajaran penemuan terbimbing, siswa juga belajar pemecahan masalah secara mandiri dan keterampilan-keterampilan berfikir kritis, karena mereka harus menganalisis dan memanipulasi informasi (Slavin, 1995). Namun dalam proses penemuan terbimbing siswa mendapat bantuan atau bimbingan dari guru agar mereka lebih terarah, sehingga baik proses pelaksanaan pembelajaran maupun tujuan yang dicapai terlaksana dengan baik. Bimbingan guru yang dimaksud adalah memberikan bantuan agar siswa dapat memahami tujuan kegiatan yang dilakukan dan arahan tentang prosedur kerja yang perlu dilakukan dalam kegiatan pembelajaran.

Berdasarkan pemasalahan penelitian di atas, maka masalah pada penelitian dirumuskan sebagai berikut ini: "Apakah peningkatan keterampilan berpikir kritis matematis siswa yang menggunakan model penemuan terbimbing lebih baik daripada siswa yang menggunakan model konvensional?"

Tujuan yang akan dicapai dari penelitian ini adalah Mendapatkan gambaran tentang peningkatan keterampilan berpikir kritis matematis siswa yang mendapatkan model penemuan terbimbing dibandingkan dengan siswa yang mendapatkan model konvensional.

\section{B. KAJIAN TEORI DAN METODE}

\section{Kajian Teori}

\section{a. Pembelajaran Model Penemuan Terbimbing}

Dalam model pembelajaran dengan penemuan terbimbing, peran siswa cukup besar karena pembelajaran tidak lagi terpusat pada guru tetapi pada siswa. Guru memulai kegiatan belajar mengajar dengan menjelaskan kegiatan yang akan dilakukan siswa dan mengorganisir kelas untuk kegiatan seperti pemecahan masalah, investigasi atau aktivitas lainnya. Pemecahan masalah merupakan suatu tahap yang penting dan menentukan. Ini dapat dilakukan secara individu maupun kelompok. Dengan membiasakan siswa dalam kegiatan pemecahan masalah dapat diharapkan akan meningkatkan kemampuan siswa dalam mengerjakan soal matematika, karena siswa dilibatkan dalam berpikir matematika pada saat manipulasi, eksperimen, dan menyelesaikan masalah. 
Menurut Markaban, langkah-langkah pembelajaran ini adalah sebagai berikut.

a. Merumuskan masalah yang akan diberikan kepada siswa dengan data secukupnya, perumusannya harus jelas, hindari pernyataan yang menimbulkan salah tafsir sehingga arah yang ditempuh siswa tidak salah.

b. Dari data yang diberikan guru, siswa menyusun, memproses, mengorganisir, dan menganalisis data tersebut. Dalam hal ini, bimbingan guru dapat diberikan sejauh yang diperlukan saja. Bimbingan ini sebaiknya mengarahkan siswa untuk melangkah ke arah yang hendak dituju, melalui pertanyaanpertanyaan, atau LKS.

c. Siswa menyusun konjektur (prakiraan) dari hasil analisis yang dilakukannya.

d. Bila dipandang perlu, konjektur yang telah dibuat siswa tersebut di atas diperiksa oleh guru. Hal ini penting dilakukan untuk meyakinkan kebenaran prakiraan siswa, sehingga akan menuju arah yang hendak dicapai.

e. Apabila telah diperoleh kepastian tentang kebenaran konjektur tersebut, maka penyampaian dan penulisan konjektur sebaiknya diserahkan juga kepada siswa untuk disusun. Di samping itu perlu diingat pula bahwa induksi tidak menjamin $100 \%$ kebenaran konjektur.

Sesudah siswa menemukan apa yang dicari, hendaknya guru menyediakan soal latihan atau soal tambahan untuk memeriksa apakah hasil penemuan itu benar (Markaban, 2006:15).

\section{1) Kemampuan Berpikir Kritis}

Berpikir merupakan suatu aktivitas mental untuk membantu memecahkan masalah, membuat keputusan, atau memenuhi rasa keingintahuan. Kemampuan berpikir terdiri dari dua yaitu kemampuan berpikir dasar dan kemampuan berpikir tingkat tinggi. Kemampuan berpikir dasar (lower order thinking) hanya menggunakan kemampuan terbatas pada hal-hal rutin dan bersifat mekanis, misalnya menghafal dan mengulangulang informasi yang diberikan sebelumnya. Sementara, kemampuan berpikir tinggi (higher order thinking) membuat siswa untuk mengintrepretasikan, menganalisa atau bahkan mampu memanipulasi informasi sebelumnya sehingga tidak monoton. Kemampuan berpikir tinggi (higher order thinking) digunakan apabila seseorang menerima informasi baru dan menyimpannya untuk kemudian digunakan atau disusun kembali untuk keperluan pemecahan masalah berdasarkan situasi.

Berpikir kritis adalah berpikir yang memeriksa, menghubungkan, dan mengevaluasi semua aspek dari situasi atau masalah. Termasuk di dalamnya mengumpulkan, mengorganisir, mengingat, dan menganalisa informasi. Berpikir kritis termasuk kemampuan membaca dengan pemahaman dan mengidentifikasi materi yang dibutuhkan dan tidak dibutuhkan. Ini juga berarti mampu menarik kesimpulan dari data yang diberikan dan mampu menentukan ketidakkonsistenan dan pertentangan dalam sekelompok data. Berpikir kritis adalah analitis dan refleksif.

Berpikir kreatif sifatnya orisinil dan reflektif. Hasil dari keterampilan berfikir ini adalah sesuatu yang kompleks. Kegiatan yang dilakukan di antaranya menyatukan ide, menciptakan ide baru, dan menentukan efektifitasnya. Berpikir kreatif meliputi juga kemampuan menarik kesimpulan yang biasanya menemukan hasil akhir yang baru.

Dua tingkat berpikir terakhir inilah (berpikir kritis dan berpikir kreatif) yang disebut sebagai keterampilan berpikir tingkat tinggi yang harus dikembangkan dalam pembelajaran matematika. Dalam hal ini akan dibahas mengenai kemampuan berpikir kritis dalam pembelajaran matematika.

\section{2) Pengertian Berfikir Kritis}

Istilah berpikir kritis (critical thinking) sering disamakan artinya dengan berpikir konvergen, berpikir logis (logical thinking) dan reasoning. R.H Ennis, dalam Hassoubah (2004), mengungkapkan bahwa berpikir kritis adalah berpikir secara beralasan dan reflektif dengan menekankan pembuatan keputusan tentang apa yang harus dipercayai atau dilakukan. Oleh karena itu, indikator kemampuan berpikir kritis dapat diturunkan dari aktivitas kritis siswa sebagai berikut :

a) Mencari pernyataan yang jelas dari setiap pertanyaan.

b) Mencari alasan.

c) Berusaha mengetahui informasi dengan baik.

d) Memakai sumber yang memiliki kredibilitas dan menyebutkannya.

e) Memperhatikan situasi dan kondisi secara keseluruhan.

f) Berusaha tetap relevan dengan ide utama.

g) Mengingat kepentingan yang asli dan mendasar. 
h) Mencari alternatif.

i) Bersikap dan berpikir terbuka.

j) Mengambil posisi ketika ada bukti yang cukup untuk melakukan sesuatu.

k) Mencari penjelasan sebanyak mungkin apabila memungkinkan.

1) Bersikap secara sistimatis dan teratur dengan bagian-bagian dari keseluruhan masalah.

Indikator kemampuan berpikir kritis yang diturunkan dari aktivitas kritis no. 1 adalah mampu merumuskan pokok-pokok permasalahan. Indikator yang diturunkan dari aktivitas kritis no. 3,4 , dan 7 adalah mampu mengungkap fakta yang dibutuhkan dalam menyelesaikan suatu masalah. Indikator yang diturunkan dari aktivitas kritis no. 2, 6, dan 12 adalah mampu memilih argumen logis, relevan dan akurat. Indikator yang diturunkan dari aktivitas kritis no. 8 dan 10, dan 11 adalah mampu mendeteksi bias berdasarkan pada sudut pandang yang berbeda. Indikator yang diturunkan dari aktivitas kritis no. 5 dan 9 adalah mampu menentukan akibat dari suatu pernyataan yang diambil sebagai suatu keputusan.

Menurut R. Swartz dan D.N. Perkins dalam Hassoubah (2004: 86) menyatakan bahwa berpikir kritis berarti:

(1) Bertujuan untuk mencapai penilaian yang kritis terhadap apa yang akan diterima atau apa yang akan dilakukan dengan alasan yang logis.

(2) Memakai standar penilaian sebagai hasil dari berpikir kritis dalam membuat keputusan.

(3) Menerapkan berbagai strategi yang tersusun dan memberikan alasan untuk menentukan serta menerapkan standar tersebut.

(4) Mencari dan menghimpun informasi yang dapat dipercaya untuk dipakai sebagai bukti yang mendukung suatu penilaian.

Dalam rangka mengetahui bagaimana mengembangkan berpikir kritis pada diri seseorang, R.H Ennis dalam Hassoubah (2004: 87) memberikan sebuah definisi berpikir kritis adalah berpikir secara beralasan dan reflektif dengan menekankan pembuatan keputusan tentang apa yang harus dipercayai atau dilakukan. Tujuan dari berpikir kritis adalah agar dapat menjauhkan seseorang dari keputusan yang keliru dan tergesagesa sehingga tidak dapat dipertanggungjawabkan.

\section{Metode}

Metode yang digunakan dalam penelitian ini adalah metode eksperimen. Desain penelitian yang digunakan dalam penelitian ini adalah pretes postes kelompok kontrol. Dengan menggunakan desain ini subyek penelitian dibagi dalam dua kelompok, satu kelompok sebagai kelompok eksperimen dan satu kelompok lagi sebagai kelompok kontrol yang dipilih secara acak kelas.

Kelompok eksperimen adalah kelompok yang akan mendapatkan pembelajaran dengan model penemuan terbimbing. Kelompok kontrol adalah kelompok yang mendapatkan model pembelajaran konvensional.

$\begin{array}{llll}\mathrm{A} & \mathrm{O} & \mathrm{X} & \mathrm{O} \\ \mathrm{A} & \mathrm{O} & & \mathrm{O}\end{array}$

Keterangan:

$\mathrm{A}=$ Pengelompokan subjek secara acak menurut kelas

$\mathrm{O}=$ Tes (pretest dan posttest dengan soal yang sama)

$\mathrm{X}=$ Perlakuan berupa pembelajaran dengan model penemuan terbimbing

\section{HASIL DAN PEMBAHASAN}

\section{Hasil}

Data yang diolah dan dianalisis dalam penelitian ini meliputi nilai pretes dan postes dari kemampuan berpikir kritis matematis siswa kelas eksperimen dan kelas kontrol.

Tabel 1. Kemampuan Awal Berpikir Kritis Matematis Kelas Eksperimen dan Kelas Kontrol

\begin{tabular}{ccc}
\hline & $\begin{array}{c}\text { Pretes } \\
\text { Kelas } \\
\text { Kontrol }\end{array}$ & $\begin{array}{c}\text { Pretes Kelas } \\
\text { Eksperimen }\end{array}$ \\
\hline $\mathbf{N}$ & $\mathbf{3 3}$ & $\mathbf{3 4}$ \\
Mean & 6.515 & $\mathbf{9 . 1 1 8}$ \\
Std Deviation & 8.704 & $\mathbf{8 . 8 3 1}$ \\
Minimum & 0 & $\mathbf{0}$ \\
Maximum & 25 & $\mathbf{2 5}$ \\
\hline
\end{tabular}

Tabel 2. Uji Normalitas Kolmogorov-Smirnov Kemampuan Awal Berpikir Kreatif Siswa pada Kelas Eksperimen dan Kelas Kontrol Kelas KolmogorovSmirnov Stati Df Sig

$\begin{array}{llll}\text { Pretes Eks } \quad .227 \quad 34 & .000\end{array}$

$\begin{array}{llll}\text { Pretes Kontrol } \quad .139 \quad 33 & .108\end{array}$


Berdasarkan Tabel 2 terlihat bahwa diperoleh nilai signifikansi kelas eksperimen kurang dari 0,05, maka $H_{0}$ ditolak. Hal ini menunjukkan bahwa data kemampuan awal berpikir kreatif siswa kelas eksperimen berasal dari data yang tidak berdistribusi normal. Sedangkan nilai signifikansi untuk kelas kontrol lebih dari 0,05, maka $H_{0}$ diterima. Hal ini menunjukkan bahwa data kemampuan awal berpikir kreatif siswa kelas kontrol berasal dari data yang berdistribusi normal. Berdasarkan hasil uji normalitas pada kelas eksperimen maupun kelas kontrol disimpulkan bahwa kelas eksperimen tidak berdistribusi normal dan kelas kontrol berdistribusi normal. Karena kedua data yang diolah berbeda, maka pengujian data selanjutnya adalah menggunakan statistik non-parametrik.

Tabel 3. Uji Kesamaan Kemampuan Awal berpikir Kreatif Siswa Kelas eksperimen dan Kelas Kontrol

\begin{tabular}{cc}
\hline & PRETES \\
\hline Mann-Whitney U & 382.000 \\
Wilcoxon W & 943.000 \\
Z & -2.280 \\
Asymp.Sig.(2-tailed) & .023 \\
\hline
\end{tabular}

Berdasarkan Tabel 3 dapat dilihat bahwa nilai Signifikansi (2-tailed) sebesar 0,023. Karena 0,023 $<0,05$, maka $\mathrm{H}_{0}$ ditolak. Hal ini menunjukkan bahwa kedua rata-rata nilai pretes berbeda secara signifikan atau dapat dijelaskan bahwa keterampilan awal berpikir kritis matematis siswa kelas eksperimen dengan kelas kontrol berbeda.

Peningkatan kemampuan berpikir kritis matematis siswa yang memperoleh pembelajaran dengan model penemuan terbimbing dan model konvensional diperoleh dari nilai n-gain. Hal ini dilakukan karena kemampuan awal berpikir kritis siswa kelas eksperimen dan kelas kontrol berbeda. Peningkatan keterampilan berpikir kritis matematis siswa diperoleh dari $n$-gain nilai pretes dan postes. $\mathrm{N}$-gain dihitung dengan rumus n-gain dari Meltzer (Dahlia, 2008: 49), yaitu:

$$
\begin{aligned}
& \text { Nilai } n-\text { Gain } \\
& =\frac{\text { Nilai Postes }- \text { Nilai Pretes }}{\text { Standar Maksimum Ideal }- \text { Nilai Pretes }}
\end{aligned}
$$

Setelah diperoleh nilai postes, dihitung nilai n-gain menggunakan rumus yang telah diberikan.

Untuk mengetahui hasil perhitungan statistik deskriptif gain kelas kontrol dan eksperimen, telah disajikan dalam Tabel 4
Tabel 4. Kemampuan Berpikir Kritis

Matematis Siswa Setelah Mengikuti

Pembelajaran dengan Model Penemuan

Terbimbing dan Model Konvensional

\begin{tabular}{ccccccc}
\hline Variable & \multicolumn{6}{l}{ N Mean SE Mean StDev Min } \\
\hline Eksp & 34 & 0.3211 & 0.0127 & 0.0738 & 0.1111 & 0.4667 \\
Kontrol & 33 & 0.1906 & 0.0164 & 0.0945 & 0.0125 & 0.3200
\end{tabular}

Berdasarkan Tabel 4, didapat deskripsi n-gain kemampuan berpikir kritis matematis siswa setelah mengikuti pembelajaran dengan model penemuan terbimbing dan model konvensional yaitu jumlah siswa yang dilihat n-gainnya ada 33 siswa di kelas kontrol dan 34 siswa di kelas eksperimen. n-gain terkecil yang didapat siswa kelas kontrol dan kelas eksperimen berturut-turut yaitu 0,0125 dan 0,1111. n- gain terbesarnya 0,3200 untuk kelas kontrol dan 0,4667 untuk kelas eksperimen. Rata-rata n-gain untuk kelas kontrol 0,1906, sedangkan untuk kelas eksperimen 0,3211. Deviasi standar n-gain untuk kelas kontrol adalah 0,0945, sedangkan untuk kelas eksperimen 0,0738. Jika dilihat, rata-rata n-gain kemampuan berpikir kritis matematis siswa kedua kelas adalah berbeda, berikutnya akan dibuktikan apakah perbedaan tersebut berarti secara statistik atau tidak, dengan langkah-langkah sebagai berikut:

Tabel 5. Uji Normalitas Kolmogorov-Smirnov N-Gain Kemampuan Berpikir Kritis Matematis Siswa pada Kelas Eksperimen dan kelas kontrol

\begin{tabular}{|c|c|c|c|}
\hline \multirow{2}{*}{ Kelas } & \multicolumn{3}{|c|}{$\begin{array}{c}\text { Kolmogorov- } \\
\text { Smirnov }\end{array}$} \\
\cline { 2 - 4 } & $\begin{array}{c}\text { Statisti } \\
\text { c }\end{array}$ & Df & Sig \\
\hline Gain Eks & .123 & 34 & .200 \\
Gain Kontrol & .177 & 33 & .100 \\
\hline
\end{tabular}

Berdasarkan Tabel 5 terlihat bahwa dengan menggunakan uji Kolmogorov mirnov diperoleh nilai signifikansi kelas kontrol dan kelas eksperimen berturut-turut 0,100 dan 0,200 . Nilai Signifikansi untuk kelas eksperimen dan kelas kontrol lebih dari 0,05 , artinya $H_{0}$ diterima. Hal ini menunjukkan bahwa peningkatan kemampuan berpikir kritis matematis siswa kelas eksperimen dan kelas kontrol berasal dari data yang berdistribusi normal. 


\section{Tabel 6. Uji Homogenitas Indeks Gain \\ Kemampuan Berpikir Kritis Matematis Siswa pada Kelas Eksperimen dan Kelas Kontrol}

\begin{tabular}{lcc}
\hline & \multicolumn{2}{c}{$\begin{array}{c}\text { Levene's Test } \\
\text { for Equality of } \\
\text { Variances }\end{array}$} \\
\hline N-Gain Equal Variances assumed & $\mathrm{F}$ & Sig \\
N-Gain Equal variances not assumeed & .229 & .587 \\
\hline
\end{tabular}

Berdasarkan Tabel 6 bahwa dengan menggunakan uji statistik parametrik diperoleh nilai signifikansi uji homogenitasnya yaitu $0,587>0,05$, yang berarti bahwa kedua kelas mempunyai varians yang homogen. Berdasarkan hasil uji normalitas dan homogenitas untuk kelas eksperimen dan kelas kontrol pada n-gain kemampuan berpikir kritis matematis siswa, disimpulkan bahwa kedua kelas mempunyai data yang berdistribusi normal dan homogen. Oleh karena itu, untuk selanjutnya dilakukan uji perbedaan dua rata-rata n-gain kemampuan berpikir kritis matematis siswa.

Tabel 7. Uji Perbedaan Dua Rata-rata N-Gain Kemampuan Berpikir Kritis Matematis Siswa

\begin{tabular}{|c|c|c|c|c|c|c|c|}
\hline & \multirow[b]{3}{*}{$\mathrm{t}$} & \multirow[b]{3}{*}{$\mathrm{df}$} & \multicolumn{5}{|c|}{ t-test for Equality of Means } \\
\hline & & & \multirow{2}{*}{$\begin{array}{l}\text { Sig. } \\
(2- \\
\text { taile } \\
\text { d) }\end{array}$} & \multirow{2}{*}{$\begin{array}{c}\text { Mean } \\
\text { Differen } \\
\text { ce }\end{array}$} & \multirow{2}{*}{$\begin{array}{c}\text { Std. } \\
\text { Error } \\
\text { Differen } \\
\text { ce }\end{array}$} & \multicolumn{2}{|c|}{$\begin{array}{l}95 \% \text { Confidence } \\
\text { Interval of the } \\
\text { Difference }\end{array}$} \\
\hline & & & & & & Lower & Upper \\
\hline $\begin{array}{l}\text { Equal } \\
\text { variances } \\
\text { assumed }\end{array}$ & 5.42 & 65 & .000 & .10933 & .02017 & .0690 & .14962 \\
\hline $\begin{array}{l}\text { Equal } \\
\text { variances } \\
\text { not } \\
\text { assumed }\end{array}$ & $\begin{array}{r}5.41 \\
8\end{array}$ & 64.860 & .000 & .10933 & .02018 & .0690 & .14963 \\
\hline
\end{tabular}

Untuk membandingkan rata-rata dengan uji-t sebaiknya menggunakan pengasumsian bahwa varians kelompok adalah sama (Equal variance assumed). Berdasarkan Tabel 7 dapat dilihat bahwa nilai $\mathrm{t}_{\text {hitung }}=5.420$. Karena nilai thitung $>$ $\mathrm{t}(0,95) 29=1,70$, maka Ho ditolak. Pengujian ini menunjukkan bahwa peningkatan kemampuan berpikir kritis matematis siswa kelas eksperimen lebih baik dari kelas kontrol.

Berdasarkan hasil pada tabel menunjukan nilai rata-rata n-gain kemampuan berpikir kritis siswa kelas eksperimen adalah 0,109. Karena 0,109 < 0,30. Ini berarti, n-gain keterampilan berpikir kritis matematis siswa kelas eksperimen berada pada taraf rendah

\section{Pembahasan}

Penelitian dilakukan dengan memberikan perlakuan yang berbeda antara kelas eksperimen dan kelas kontrol, perlakuan yang diberikan pada kelas eksperimen adalah pembelajaran yang menggunakan model penemuan terbimbing, sedangkan perlakuan yang diberikan pada kelas control adalah pembelajaran konvensional. Peningkatan kemampuan berpikir kritis matematis siswa SMP yang pembelajarannya menggunakan model penemuan terbimbing lebih baik daripada yang menggunakan model konvensional. Hal ini terjadi karena siswa dapat memecahkan masalahnya dengan sendirinya, mereka dilatih untuk dapat menemukan jawaban sendiri atas permasalahan yang mereka hadapi

\section{KESIMPULAN}

Berdasarkan penelitian dan pembahasan, maka dapat ditarik kesimpulan penelitian bahwa Peningkatan kemampuan berpikir kritis matematis siswa yang mendapatkan pembelajaran dengan model penemuan terbimbing lebih baik daripada siswa yang mendapatkan pembelajaran dengan model konvensional.

\section{E. DAFTAR PUSTAKA}

Departemen Pendidikan Nasional (2007). Pedoman Penulisan Karya Ilmiah. Bandung: Universitas Pendidikan Indonesia.

Ennis, R.H. (1985). Developing Mind: Goal for a Critical Thinking Curriculum. Arethur L.Costa Editor.

Hassoubah, Z. I. (2004). Develoving Creative \& Critical Thinking Skills (Cara Berpikir Kreatif dan Kritis). Bandung: Yayasan Nuansa Cendekia.

Indrawati (2007). Keterampilan Berpikir Dasar. Bandung: Depdiknas.

Jamal (2011). Peningkatan Kemampuan Berpikir Kreatif Siswa Sekolah Menengah Pertama melalui Pembelajaran dengan Metode Penemuan dan Penemuan Terbimbing. Skripsi Sarjana Pada FPMIPA UPI Bandung: tidak diterbitkan.

$\begin{array}{ccr}\text { Markaban (2006). } & \text { Model } & \text { Pembelajaran } \\ \text { Matematika } & \text { Dengan } & \text { Pendekatan } \\ \text { Penemuan } & \text { Terbimbing. } & \text { Yogyakarta: } \\ \text { PPPPTK Matematika } & \end{array}$


Ruseffendi, H.E.T. (2010). Dasar-dasar Penelitian Pendidikan dan Bidang Non Eksakta lainnya. Bandung : Tarsito

Slavin, R. E. (1995), Cooperative learning ; Theory, Research, and Practice, seconded. Boston: Allyn and Bacon.

Sugiyono (2008). Metode Penelitian Penelitian (Pendekatan Kuantitatif, Kualitatif, dan $R \& D)$. Bandung: Alfabeta.

Suherman, et al. (2003). Strategi Pembelajaran Matematika Kontemporer. JICA FPMIPA UPI.

Turmudi (2001). Strategi Pembelajaran Matematika Kontemporer, Bandung, JICAUniversitas Pendidikan Indonesia (UPI).

Wahyudin, dkk. (2002). Kapita Selekta Matematika Sekolah. Bandung: UPI 